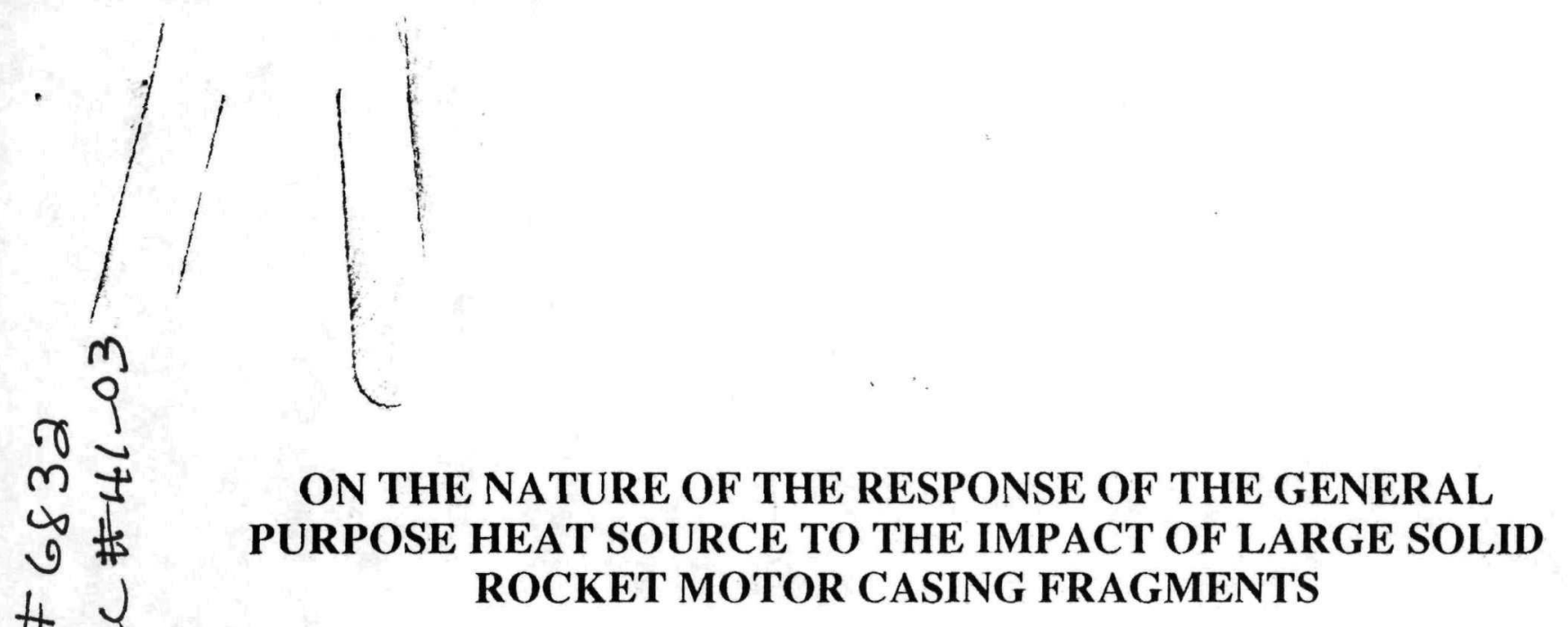

Marshall Eck and Meera Mukunda

Fairchild Space Company

Germantown, MD 20874

(310) 428-6273

SUMMARY prepared for:

Sixth Symposium

on Space Nuclear Power Systems

Albuquerque, New Mexico

9-12 January 1989

The work summarized in this paper was supported by the U.S. Department of Energy, Office of Special Applications 


\section{DISCLAIMER}

This report was prepared as an account of work sponsored by an agency of the United States Government. Neither the United States Government nor any agency Thereof, nor any of their employees, makes any warranty, express or implied, or assumes any legal liability or responsibility for the accuracy, completeness, or usefulness of any information, apparatus, product, or process disclosed, or represents that its use would not infringe privately owned rights. Reference herein to any specific commercial product, process, or service by trade name, trademark, manufacturer, or otherwise does not necessarily constitute or imply its endorsement, recommendation, or favoring by the United States Government or any agency thereof. The views and opinions of authors expressed herein do not necessarily state or reflect those of the United States Government or any agency thereof. 


\section{DISCLAIMER}

Portions of this document may be illegible in electronic image products. Images are produced from the best available original document. 


\title{
ON THE NATURE OF THE RESPONSE OF THE GENERAL PURPOSE HEAT SOURCE TO THE IMPACT OF LARGE SOLID ROCKET MOTOR CASING FRAGMENTS
}

\author{
Marshall Eck and Meera Mukunda \\ Fairchild Space Company \\ 20301 Century Boulevard \\ Germantown, MD 20874
}

(301) 428-6273

The General Purpose Heat Source (GPHS) was developed by U.S. Department of Energy (DOE) personnel and their contractors to provide a safe and mass efficient method of packaging the radioactive isotope Pu-238 for use in space power systems. The characteristics of this heat source and its development history are well documented in numerous reports and papers and will not be revisited here.

Most of the GPHS Safety Verification Tests (SVT) focused on demonstrating the ability of the modules to survive launch abort explosions and fires, reentry heating, and post-reentry impact on rigid surfaces. The Challenger (STS-51L) accident demonstrated that Solid Rocket Motor (SRM) casing failure could produce large, high velocity, fragments. At the time of the accident, the ability of the GPHS modules to withstand impacts of fragments of this caliber and velocity had not been demonstrated either by analysis or test. Once the magnitude of this problem was assessed, DOE management initiated a program to determine the response of the GPHS-RTG to the impact of SRM casing fragments of the type and velocity witnessed in the $51 \mathrm{~L}$ event ${ }^{(1),(2)}$. This program required the designers to use analysis and test in a serial manner to make the best use of the available hardware and test facilities. Using existing gas gun facilities, the maximum velocity at which Pu-238 fueled capsules could be tested in a constrained module configuration was $120 \mathrm{~m} / \mathrm{s}$. The maximum fragment size which could be tested was $30.5 \times 40.6 \mathrm{~cm}$. The $51 \mathrm{~L}$ event showed that SRM quadrant sized fragment having velocities of approximately $200 \mathrm{~m} / \mathrm{s}$ were generated at a Mission Elapsed Time (MET) of 110 seconds. The rocket sleds which were available to test fragments of this size were not in contained facilities; hence, they could not be used to test Pu-238 fueled modules.

The subject of this paper is the process used to perform macro calibrations of analytical models and their application to predict the GPHS modules' response to serially increasing levels of test

Table 1. Summary of Material Properties Used in the SRM Fragment Impact Analyses

\begin{tabular}{|c|c|c|c|c|c|c|c|c|c|c|c|}
\hline \multirow[t]{2}{*}{ MATERIAL } & \multicolumn{6}{|c|}{ EQUATION OF STATE } & \multicolumn{3}{|c|}{ YIELD MODEL } & \multirow[b]{2}{*}{ HTALL } & \multirow[t]{2}{*}{ DATA SOURCE } \\
\hline & TYPE & (a) & $\begin{array}{c}\text { BULK } \\
\text { MODULUS } \\
\text { KBAR }\end{array}$ & $\begin{array}{c}Y_{1} \\
\text { KBAR }\end{array}$ & $\begin{array}{c}Y 2 \\
\text { KBAR }\end{array}$ & $\begin{array}{l}\text { REF. } \\
\text { DENSITY } \\
(\rho 0) \\
\text { gm/cc }\end{array}$ & TYPE & $\begin{array}{c}\text { SHEAR } \\
\text { MODULUS } \\
\text { KBAR }\end{array}$ & $\begin{array}{c}\text { YIELD } \\
\text { STRENGTH } \\
\text { KBAR }\end{array}$ & & \\
\hline WEAK PLUTONIA (PU2H6H) & $P-a$ & 0.84 & 730. & 0.677 & 1.33 & 11.5 & $\begin{array}{l}\text { VON } \\
\text { MISES }\end{array}$ & 270. & 0.677 & 0.200 & \multirow{2}{*}{$\begin{array}{l}\text { LOS ALAMOS DATA SHEETS } \\
\text { MAY } 1986\end{array}$} \\
\hline STRONG PLUTONIA (PU4H 13H) & P-a & 0.84 & 730. & 1.30 & 1.33 & 11.5 & $\begin{array}{l}\text { VON } \\
\text { MISES }\end{array}$ & 270 & 1.30 & 0.400 & \\
\hline WEAK URANIA (U6H11H) & P-a & 0.87 & 1370. & 1.10 & 1.22 & 11.0 & $\begin{array}{l}\text { VON } \\
\text { MISES }\end{array}$ & & 1.10 & 0.600 & \multirow{2}{*}{$\begin{array}{l}\text { LOS ALAMOS DATA SHEETS } \\
\text { MAY } 1986\end{array}$} \\
\hline STRONG URANIA (U8H12H) & P-a & 0.87 & 1370. & 1.20 & 1.22 & 11.0 & $\begin{array}{l}\text { VON } \\
\text { MISES }\end{array}$ & 598. & 1.20 & 0.800 & \\
\hline POCO GAAPHITE & $\begin{array}{l}\text { POLY- } \\
\text { NOMIAL }\end{array}$ & - & 301. & & & 1.98 & $\begin{array}{l}\text { VON } \\
\text { MISES }\end{array}$ & 20. & 0.50 & 1.0 & \multirow{2}{*}{$\begin{array}{l}\text { W.W. TAABELL (1979) } \\
\text { AFWL-TR-79-38 }\end{array}$} \\
\hline 3-D GRAPHITE & SHOCK & - & 25.9 & & & 1.95 & $\begin{array}{l}\text { VON } \\
\text { MISES }\end{array}$ & 20. & 1.00 & 1.0 & \\
\hline IRIDIUM & $\begin{array}{l}\text { POLY- } \\
\text { NOMIAL }\end{array}$ & - & 3510. & & & 22.5 & $\begin{array}{l}\text { VON } \\
\text { MISES }\end{array}$ & 1618. & 2.00 & 1000. & $\begin{array}{l}\text { ORNL-5611 APRIL } 1980 \text { (c) } \\
\text { FSAR GESP } 7200 \text { AUGUST } 1985\end{array}$ \\
\hline INSULATION-TIE & $P-a$ & 0.59 & 8.9 & & & 0.90 & $\begin{array}{l}\text { VON } \\
\text { MISES }\end{array}$ & 6.7 & 1.00 & 0.1 & $\begin{array}{l}\text { GE MEMO (b) } \\
\text { C.J. EARDLEY } 1 / 7 / 88\end{array}$ \\
\hline ALUMINIUM & $\begin{array}{l}\text { POLY- } \\
\text { NOMIAL } \\
\end{array}$ & - & 765 & & & 2.77 & $\begin{array}{l}\text { VON } \\
\text { MISES }\end{array}$ & 294.0 & 6.50 & 1000. & BAKKEN \& ANDERSON, SANDIA \\
\hline D6A STEEL & $\begin{array}{l}\text { POLY- } \\
\text { NOMIAL }\end{array}$ & - & 1670. & & & 7.86 & $\begin{array}{l}\text { VON } \\
\text { MISES }\end{array}$ & 816.0 & 12.9 & 1000. & $\begin{array}{l}\text { LADISH DATA SHEET } \\
\text { FSCM \#07703 (1987) }\end{array}$ \\
\hline
\end{tabular}

(a) $a=$ DENSITY OF UNCOMPACTED MATERIAL

(b) DERIVED FROM EXPERIMENTS CONDUCTED AT GE AND MODIFIED BY FSC PERSONNEL TO ACCOUNT FOR THERMOELECTRIC ELEMENT INITIAL COMPRESSIVE STRENGTH

(c) YIELD CORRECTED FOR THE BIAXIAL TENSION CREATED BY THE ALMOST SPHERICAL NATURE OF THE IRIDIUM SHELL. 
environment complexity. The first step in this process was to develop a set of material constituative equations for plutonia and urania which would bracket the results obtained from the planned experiments. Table 1 shows the material properties used in the subsequent analyses. The terms "weak" and "strong" describe the material property sets which provided upper and lower bounds to the capsule deformation response observed in the experimental program. The protocols for the experimental program required that an analytical prediction be made prior to performing a test. As a result, with the exception of the $54 \mathrm{~m} / \mathrm{s}$ Bare Capsule Impact (BCl) test series, the authors made their analytical predictions before they knew the corresponding experimental results. This was purposely done to provide a single blind experiment.

A comparison of the analytical and experimental results for the impact of a bare GPHS urania fueled capsule on a $2.54 \mathrm{~cm}$ thick steel target is shown in Figure 1. The geometric time history of the impact of a urania-fueled capsule with an initial velocity of $76 \mathrm{~m} / \mathrm{s}$ on a $2.54 \mathrm{~cm}$ thick steel target is shown in Figure 2. Comparisons of the predicted and measured endpoint geometry of the event shown in Figure 2 are presented in Figure 3 for the urania fuel and Figure 4 for the plutonia fuel. This agreement was considered adequate for the required purposes and the calibration exercise moved to the next level of complexity.

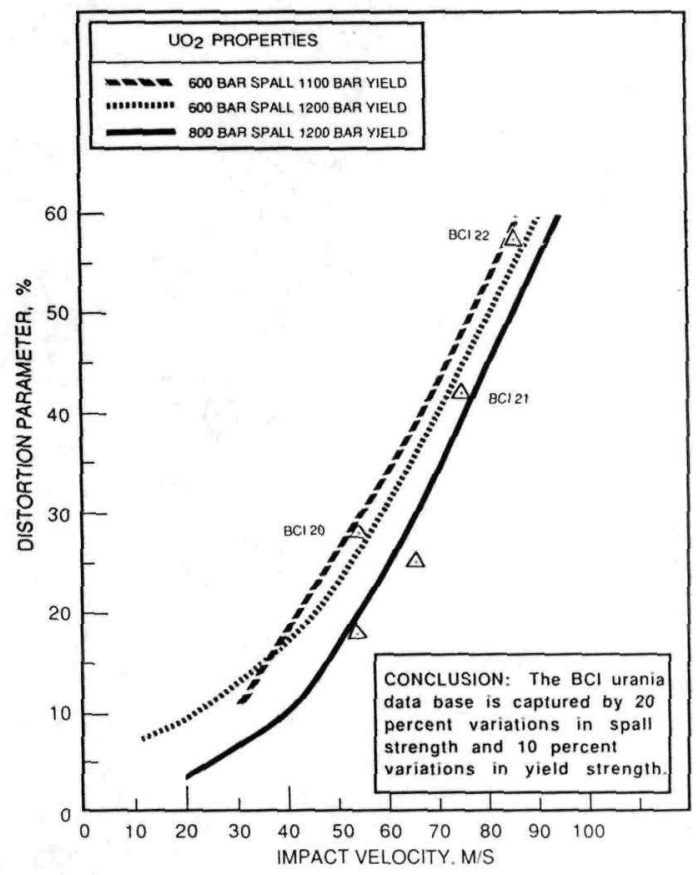

Figure 3. Bare Urania-Fueled Capsule Response to Impact on a $2.54 \mathrm{~cm}$ Thick Steel Plate (BCl Geometry)

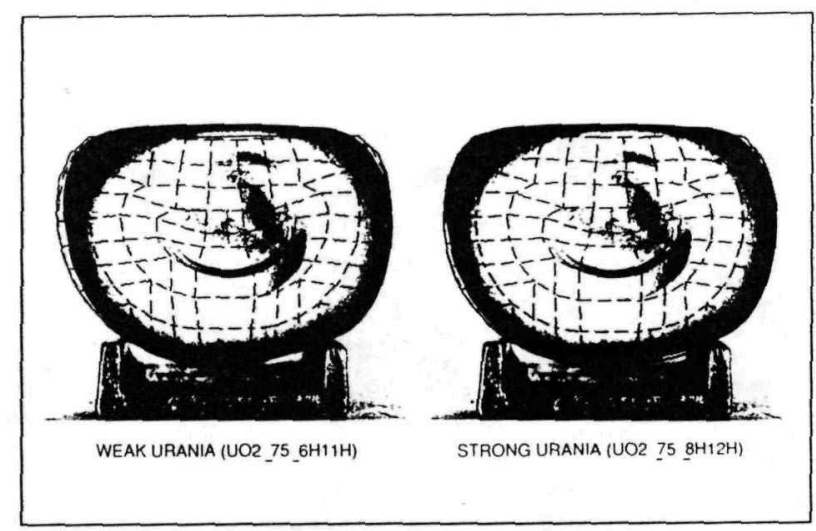

Figure 1. Effect of Simulant Properties on the Predicted Post Impact Geometry Resulting from a Urania Fueled-Capsule Impact on a $2.54 \mathrm{~cm}$ Steel Target at $75 \mathrm{~m} / \mathrm{s}$ in the BCl Geometry

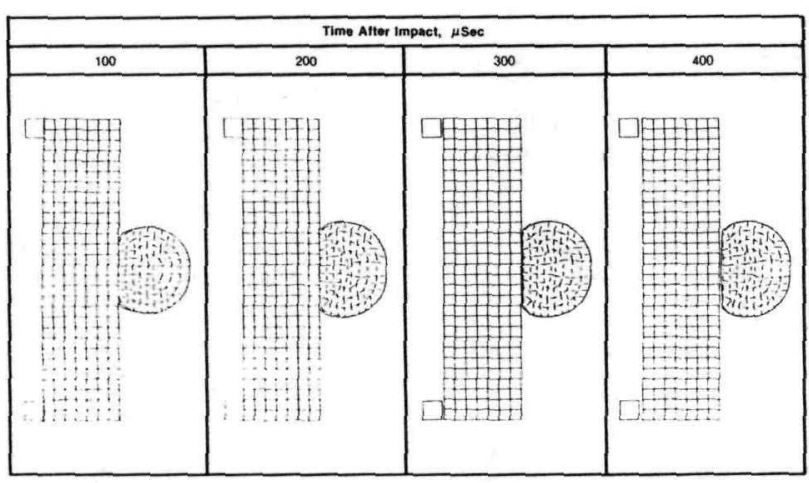

Figure 2. Predicted Response of a Urania-Fueled Capsule in the BCI 21 Event $(76 \mathrm{~m} / \mathrm{s} 2.54 \mathrm{~cm}$ Thick Steel Target)

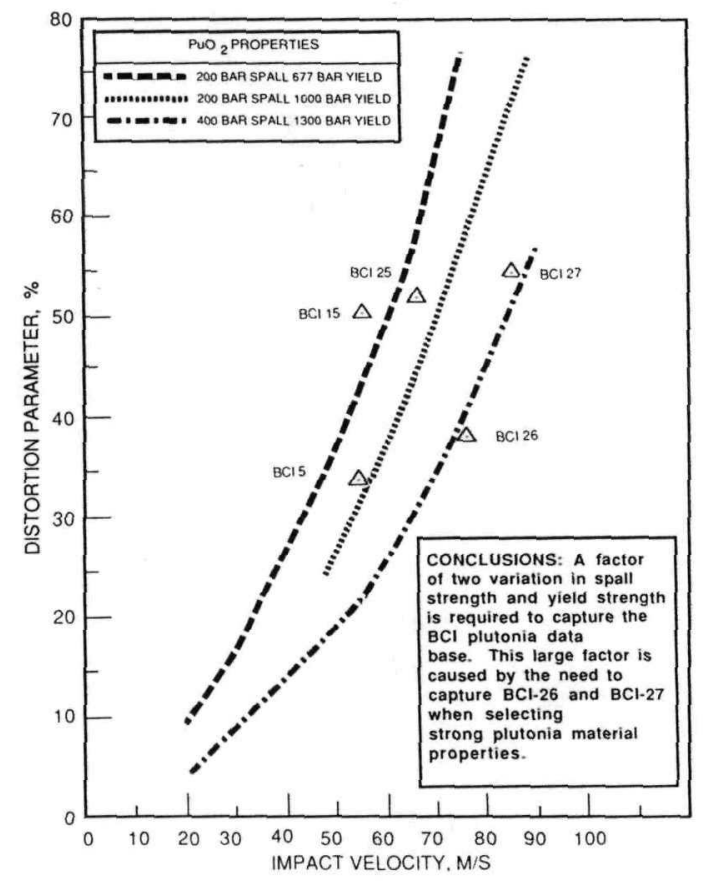

Figure 4. Plutonia-Fueled Bare GPHS Capsule Response to Impact on a $2.54 \mathrm{~cm}$ Thick Steel Target (BCl Geometry) 
The Fragment Gun Tests (FGT) were performed in the same closed facility at Los Alamos National Laboratory (LANL) which was used for the $\mathrm{BCl}$ tests. Both urania and plutonia were used in this series as was the case in the $\mathrm{BCl}$ series. The accelerated test article consisted of a prototypical urania or plutonia fueled module sandwiched between two module mass simulants (molybdum in POCO graphite), a simulated thermoelectric insulation package and a simulated generator housing section. This assembly was fired into a $30 \times 40 \mathrm{~cm}$ section of an STS-SRM casing at 100 and $120 \mathrm{~m} / \mathrm{s}$. A comparison of predicted and observed fueled capsule distortion resulting from the FGT environment is shown in Figure 5. A predicted geometric time-history of a plutonia fueled GPHS module assembly of the type described above impacting at $100 \mathrm{~m} / \mathrm{s}$ is shown in Figure 6. A comparison of the observed and predicted (weak plutonia) post-impact geometries from FGT-2 is shown in Figure 7. Based on the above, the model was judged calibrated and was then used to predict the results of the planned Large Fragment Tests (LFT).

The LFT test article could not be fueled since no contained facility which could accommodate the required fragment size and provide the required fragment velocity was available. Because of this, analysis was used to connect the expected plutonia response to the observed urania response. A model of the type shown in Figure 8 was devised to represent the test article used in the LFT. The test article in this case was a $1 / 2$ length section of the GPHS engineering test unit. This unit was impacted with a $142 \times 142$ $\mathrm{cm}$ square section of STS-SRM casing at 115 and $212 \mathrm{~m} / \mathrm{s}$. The results of these and the previously described tests are summarized in Table 2. Typical

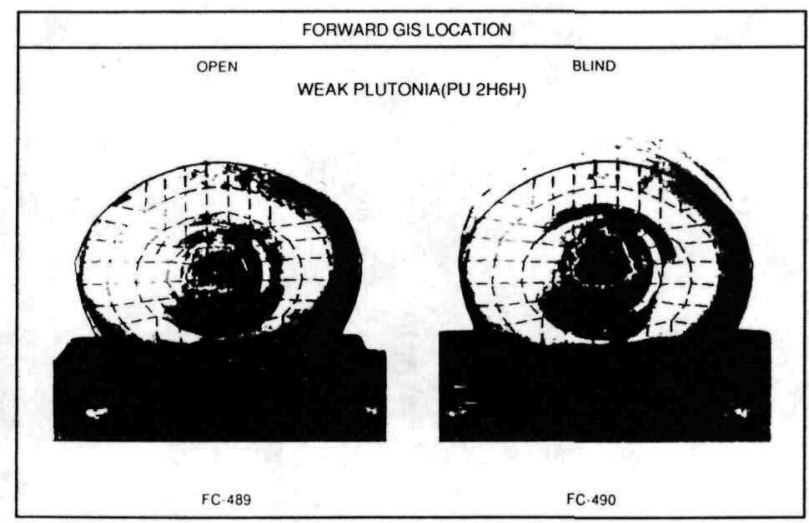

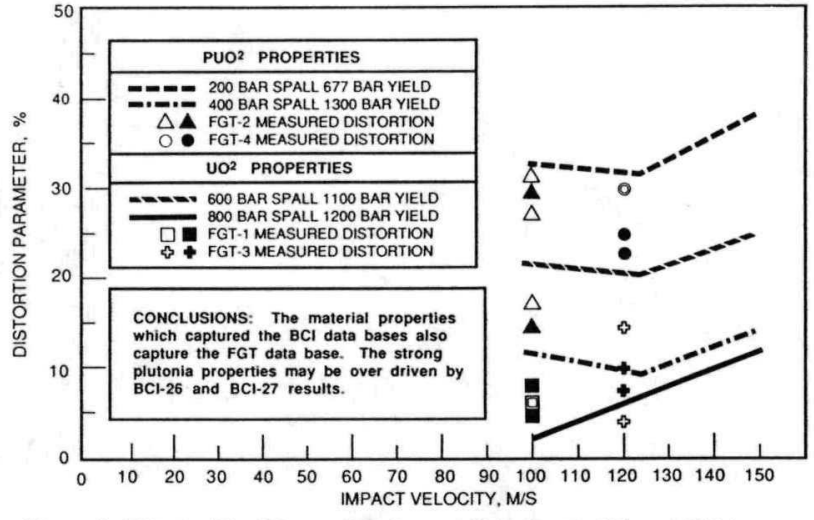

Figure 5. Effect of Fuel Properties, Impact Velocity, and Target Thickness on Predicted Forward GIS Fueled Capsule Deformation in FGTType Events

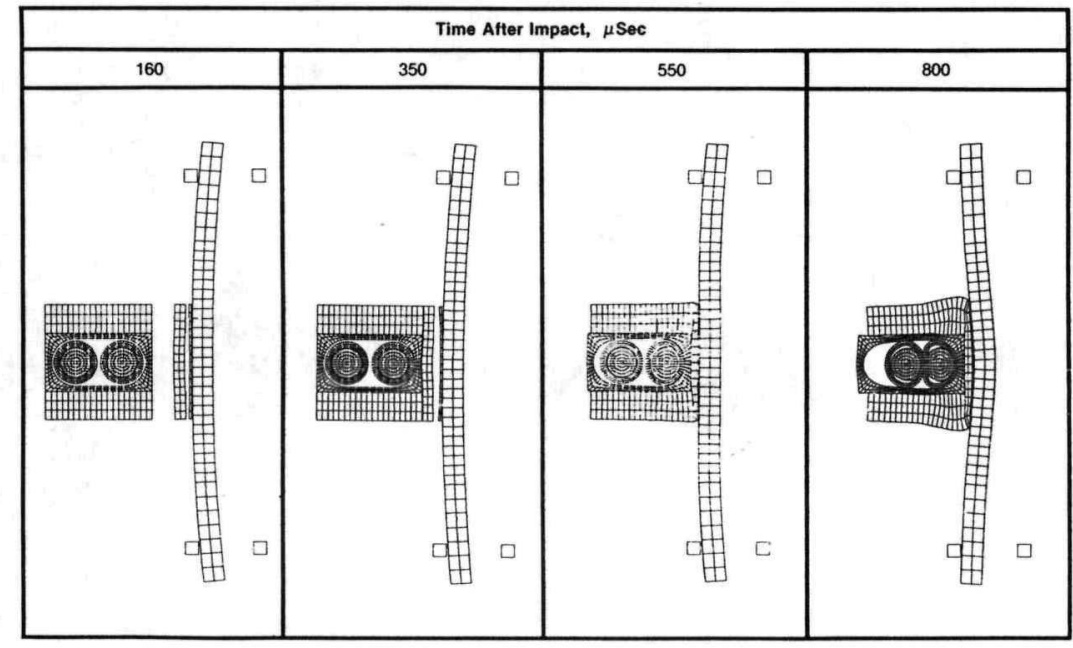

Figure 6. Predicted Response of the FGT-2 Stack to Impact at $100 \mathrm{~m} / \mathrm{s}$ on a $30 \times 40 \times 1.26 \mathrm{~cm} \mathrm{D6A}$ Steel Target
Figure 7. Comparison of Predicted and ObservedPost FGT-2 Impact
Fueled-Capsule Geometry ( $100 \mathrm{M} / \mathrm{S}$ On a $30 \times 40 \times 1.26 \mathrm{~cm}$ D6A
Steel Target, Weak Plutonia)

Figure 7. Comparison of Predicted and ObservedPost FGT-2 Impact
Fueled-Capsule Geometry ( $100 \mathrm{M} / \mathrm{S}$ On a $30 \times 40 \times 1.26 \mathrm{~cm}$ D6A
Steel Target, Weak Plutonia)

Figure 7. Comparison of Predicted and ObservedPost FGT-2 Impact
Fueled-Capsule Geometry ( $100 \mathrm{M} / \mathrm{S}$ On a $30 \times 40 \times 1.26 \mathrm{~cm}$ D6A
Steel Target, Weak Plutonia)

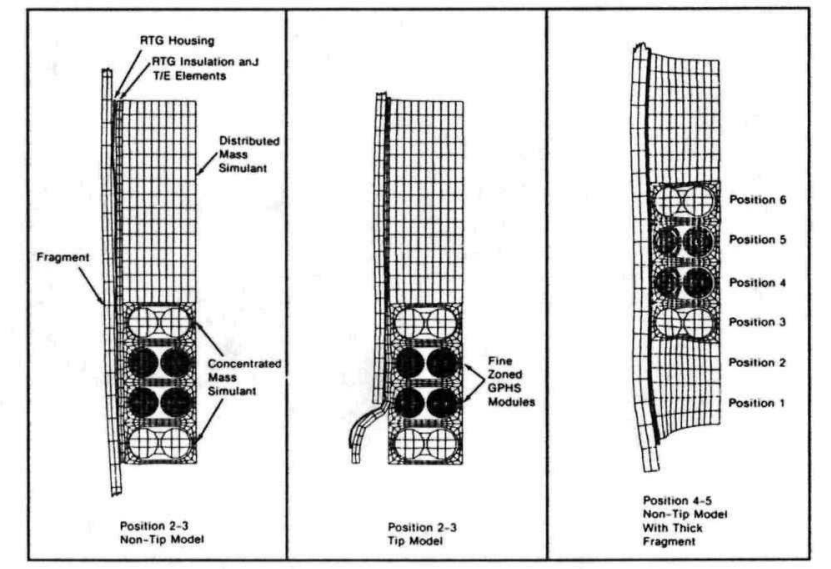

Figure 8. Models Used in Developing the SRM Fragment Data Base 
Table 2. Summary of the Large Fragment Test (LFT) Results ${ }^{(3)}$

\begin{tabular}{|c|c|c|c|c|c|c|c|c|}
\hline \multicolumn{9}{|c|}{ FORWARD CAPSULE RESPONSE TO LFT EVENTS } \\
\hline \multicolumn{9}{|c|}{ Stack Position 2} \\
\hline \multicolumn{2}{|l|}{ IMPACT VELOCITY } & \multicolumn{3}{|l|}{115} & \multicolumn{4}{|c|}{212} \\
\hline \multirow[t]{2}{*}{ LOCATION } & \multicolumn{4}{|c|}{ STRAIN } & \multicolumn{4}{|c|}{ STRAIN } \\
\hline & $\begin{array}{c}\text { DIAMETER } \\
\%\end{array}$ & $\underset{\%}{\text { HEIGHT }}$ & $\begin{array}{c}\text { LENGTH } \\
\%\end{array}$ & $\begin{array}{c}\text { PARAMETER } \\
\%\end{array}$ & $\begin{array}{c}\text { DIAMETER } \\
\%\end{array}$ & $\begin{array}{l}\text { HEIGHT } \\
\%\end{array}$ & $\begin{array}{c}\text { LENGTH } \\
\%\end{array}$ & $\begin{array}{c}\text { PARAMETER } \\
\%\end{array}$ \\
\hline OPEN VENT CUP & 0.9 & -2.9 & 1.0 & 3.9 & 1.3 & -10.8 & 10.3 & 13.5 \\
\hline OPEN SOLID CUP & 0.9 & -2.1 & & 3.1 & 1.3 & -11.2 & & 14.0 \\
\hline BLIND VENT CUP & 0.2 & -2.6 & 0.6 & 2.9 & .6 & -9.1 & 8.1 & 6.0 \\
\hline BLIND SOLID CUP & 0.9 & -2.3 & & 3.2 & - & - & - & - \\
\hline \multicolumn{9}{|c|}{ Stack Position 5} \\
\hline OPEN VENT CUP & 2.9 & -2.8 & 2.0 & 5.9 & 3 & -8.5 & 4.3 & 9.7 \\
\hline OPEN SOLID CUP & 3.1 & -2.8 & & 6.1 & .9 & -3.4 & & 4.4 \\
\hline BLIND VENT CUP & 2.8 & -4.9 & 1.8 & 8.2 & 6 & -4.3 & 8.4 & 7.0 \\
\hline BLIND SOLID CUP & 2.2 & -2.1 & & 4.4 & 3 & -4.3 & & 4.8 \\
\hline \multicolumn{9}{|c|}{ AFT CAPSULE RESPONSE TO LFT ENVIRONMENT } \\
\hline \multicolumn{9}{|c|}{ Stack Position 2} \\
\hline OPEN VENT CUP & 2.9 & -1.5 & 2.1 & 4.4 & 0.1 & -1.8 & -1.1 & 1.9 \\
\hline OPEN SOLID CUP & 2.6 & -5.7 & & 8.8 & -0.1 & -2.4 & & 2.4 \\
\hline BLIND VENT CUP & 0.3 & -0.6 & -1.3 & 0.9 & 0.9 & -2.6 & 0.2 & 3.7 \\
\hline BLIND SOLID CUP & 0.2 & -1.3 & . & 1.5 & 0.6 & -3.2 & & 4.0 \\
\hline \multicolumn{9}{|c|}{ Stack Position 5} \\
\hline OPEN VENT CUP & 0.6 & -0.1 & 0.9 & 1.6 & 0.7 & -2.6 & 0.0 & 3.4 \\
\hline OPEN SOLID CUP & 0.8 & -2.6 & & 3.6 & 1.0 & -3.1 & & 4.2 \\
\hline BLIND VENT CUP & 0.4 & -0.6 & -0.7 & 1.0 & 0.5 & -2.3 & -0.9 & 2.9 \\
\hline BLIND SOLID CUP & 0.3 & -0.9 & & 1.1 & 0.9 & -3.3 & & 4.3 \\
\hline
\end{tabular}

agreement obtained between predicted and observed results is shown in Figure 9 and Figure 10. It should be noted that simple extrapolation of the $120 \mathrm{~m} / \mathrm{s}$ FGT results would have produced very different answers than were predicted for the LFT results. The serial predictor/corrector approach used by the experimentalists and analysts was critical to obtaining the maximum possible information from the available hardware and facilities. It is hoped that the predictive power of analysis is found useful in selecting test conditions for future programs.

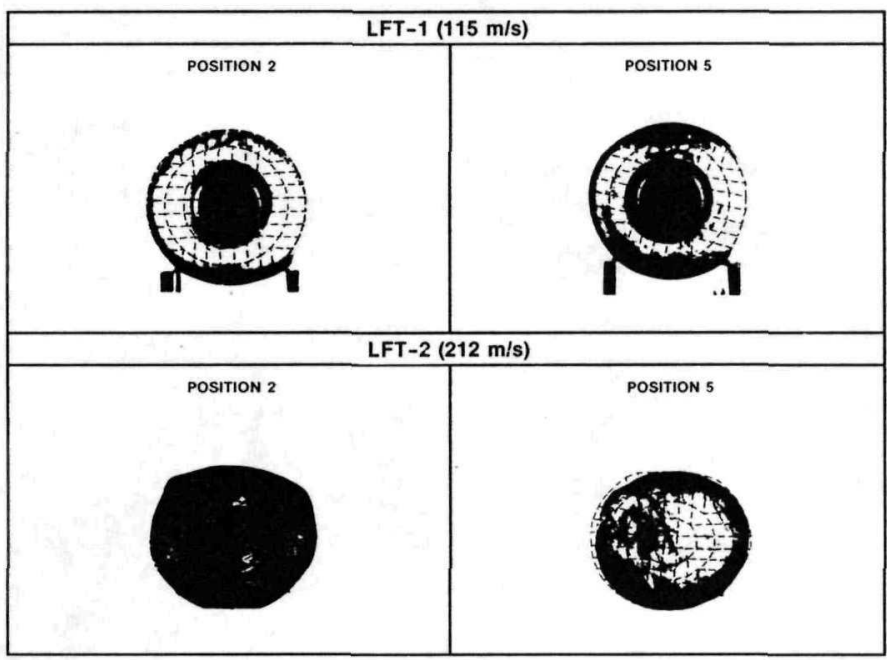

Figure 9. Forward Capsule Post Impact Geometry for the LFT-1 and LFT-2 Events

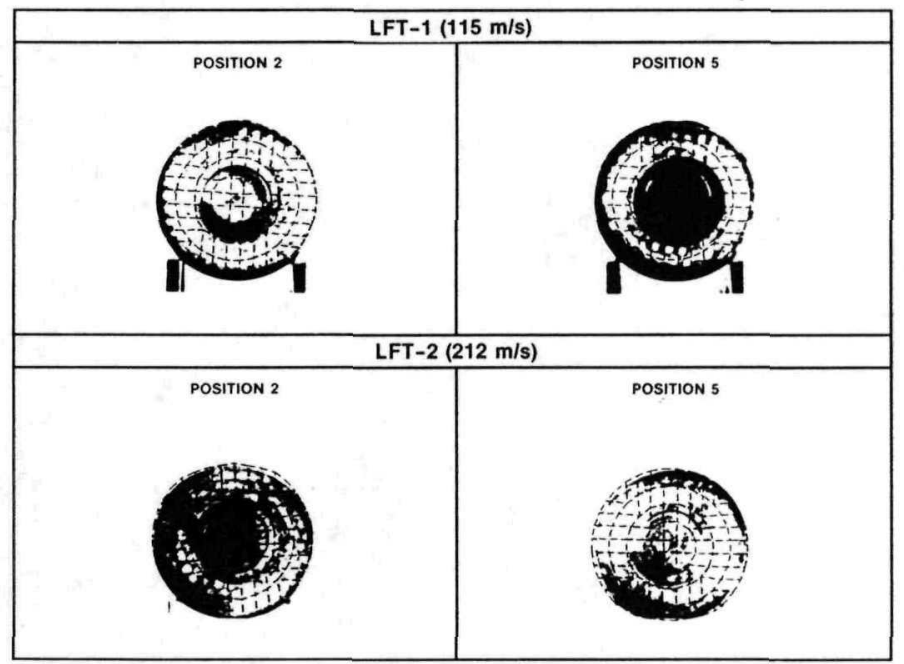

Figure 10. Aft Fueled Clad Post Impact Geometry for the LFT-1 and LFT-2 Events

\section{References}

(1) Eck, Marshall and Meera Mukunda. (1988) "Predicting the Velocity and Azimuth of Fragments Generated by the Range Destruction or Random Failure of Rocket Casings and Tankage." 39th Congress of the International Astronautical Federation, held in Bangalore, India, 10-14 October 1988.

(2) Space Shuttle Data for Planetary Mission Radioisotope Thermoelectric Generator Safety Analysis, NSTS 08116, Draft Revision A, June 2, 1987.

(3) Zocher, Roy, (1988). Personal Communication. Los Alamos National Laboratory, Los Alamos, New Mexico, September 1988.

\section{Acknowledgements}

The effort described in this paper was sponsored by the Department of Energy under contract DE-AC01-85NE32125. The authors appreciate the encouragement offered by Dr. Gary Bennett of DOE throughout the conduct of this effort. The authors also thank Tak Or of Fairchild Space Company for his assistance in mechanizing the intact RTG models. 